\title{
Leaf Protein Electrophoresis and Taxonomy of Species of Jatropha L. (Euphorbiaceae)
}

\author{
Olaniran Temitope OLADIPO*, Herbert Chukwuma ILLOH \\ Obafemi Awolowo University, Ile-Ife, Department of Botany, Nigeria; toladipo@oauife.edu.ng ( ${ }^{*}$ corresponding author)
}

\begin{abstract}
The systematic relationship existing among members of the all important genus Jatropha was studied using leaf protein electrophoresis. The aim was to identify possible taxonomic importance of the protein profile in the estimation and elucidation of the taxonomic affinity of the six species of Jatropha (Jatropha curcas Linn., J. podagrica Hook., J. gossypifolia Linn., J. mutifida Linn., J. tanjorensis Ellis \& Saroja and J. integerrima Linn.) found in Nigeria. The species were screened for total protein banding patterns using gel electrophoresis. Young leaves $(0.8 \mathrm{~g})$ of the plants were washed with distilled water and macerated with sterile mortar and pestle in $0.8 \%$ Phosphate Buffer-Saline (PBS) containing $0.4 \mathrm{M} \mathrm{NaCl}$ at $\mathrm{pH}$ 8.0. Results reveal that protein banding pattern was taxon specific. Generic band occurs at 8.3 . The highest number of interspecific bands (4) exists between J. podagrica and J. multifida. Variations exist not only in the number of bands but also in the intensity of the bands. Sokal and Sneath coefficient of similarity ranges between 11.1-44.4\%. Single linkage Cluster Analysis (SLCA) of the relative mobility values of the protein in the taxa shows partial agreement with current sub generic and sectional delimitation of the species based on morphology and anatomy of the species.
\end{abstract}

Keywords: acrylamide, clustering, delimitation, dendogram, diagnostic, morphology, single linkage

\section{Introduction}

The genus Jatropha, which belongs to the tribe Crotonae consists of c.175 species (Olowokudejo, 1993) which are mostly trees, rhizomatous sub shrubs and suffrutescent herbs (Dehgan, 1984 cited by Prabakaran and Sujatha, 1999). Members of the genus are planted as ornamentals, for medicinal purposes, and for biodiesel found in some of the species (Heller, 1996). The genus is so diverse both in vegetative and floral structure that it has been variously split or subdivided by taxonomists. Based on both the morphological and anatomical characteristics of the species of the genus Jatropha, Dehgan and Webster (1979) as well as Dehgan (1980) described the habit of the species of the genus as ranging between trees and shrubs. The genus is characterized by leaves which may be simple to palmately 3,5 or 7 lobed or divided into a maximum of 11 segments. Dehgan and Webster (1982) observed that a number of the species in the genus are long petiolate but a few taxa are sub sessile species with broad leaves and have palmate venation as against pinnate venation. Few taxa have ovatelanceolate to narrowly lanceolate leaves. Stipules, although present in various forms whether foliar, glandular, filiform or spinose, are reported to be fugacious in some species (Dehgan, 1982). Similarly, leaf sizes in the genus Jatropha have been reported to vary from $2-3 \mathrm{~mm}$ in extreme xeric habitat to $20 \mathrm{~cm}$ or more under mesic conditions. In the family Euphorbiaceae, monoecious and dioeciuos flower production are widespread with monoecious flower being more common. In the tribe Crotonae inflorescence is di- chasia and floral forms show tremendous diversity. Flowers in Jatropha have been observed by Rao (1971) to be the most primitive being often hermaphroditic. Dehgan and Webster (1979) however considered the physic nut (Jatropha curcas L. [sect. curcas (Adans.) Griseb. subg. Curcas (Adans.) Pax]) to be the most primitive form of the genus Jatropha and that species in other sections evolved from the physic nut or another ancestral form, with changes in growth habit and flower structures.

It is generally believed that chemical identification of specific compounds will provide a greater insight into the relationships and differences among plant taxa (Akpabio, 1988). David (1994) pointedly remarked that physiochemical data provide much useful information concerning relationship both within the Euphorbiaceae and between this family and relatives. The presence or absence of secondary metabolites and the biosynthetic pathways responsible for their production are useful for establishing taxonomic and phylogenetic relationship (Domingues et al., 1988). For several years now, a number of attempts have been made in several fields of Biology to place the taxonomic relationships of species upon a firm physico-chemical foundation (Moyer, 1934 cited by Webster, 1994). Most frequently used of these biochemicals in higher plants have been phenolic compounds, seed protein and isoenzymes of particular enzyme. Gotlieb (1971) stressed the importance of electrophoresis in systematics. He observed that variation in protein banding pattern can directly be equated to variation in genes coding for various proteins. Various biochemical differences between popu- 
lations have proved to be valuable aids in determining taxonomic relationship. Generally, the degree of variation in the bands has been reported by Folorunso and Olorode (2002) to depict the genetic diversity of the genera as it was in the case of the family Annonaceae. Furthermore it has been observed that the variation in the combination of protein bands at the anode is taxon specific and that no two species have the same band distribution. Hence, determining the protein banding pattern in the members of a particular taxon will help in delimiting the member at intra and intergeneric or familial levels. In his study of crude protein electrophoresis of seeds of eight species of the genus Crotalaria, Akpabio (1988) reported that seven species were related, while Crotolaria calycina was less related to the group. Hegnaeur (1989) observed that for the family Euphorbiaceae, secondary metabolites such as alkaloids, cyanogenic glycosides, diterpenes, glucosinolates, tannins and triterpenes are the most common metabolites of taxonomic importance at the suprageneric levels. In view of the complex taxonomic status of Jatropha species, this study carried out a leaf protein electrophoretic research of the genus Jatropha in Nigeria with a view to investigating the taxonomic relationship and also to clarify the circumscriptions of members of the genus in Nigeria.

\section{Materials and methods}

Electrophoretic study of the protein variations from the leaves of the six taxa studied were carried out using $12 \%$ polyacrylamide gels. The species were screened for total protein banding patterns by using a modified method of Laemli (1970) described by Aguegia et al. (1994); Omitogun et al. (1999) and Tokpo et al. (2006). Young leaves $(0.8 \mathrm{~g})$ of the plants were washed with distilled water and macerated with sterile mortar and pestle in $0.8 \%$ phosphate buffer-saline (PBS) containing $0.4 \mathrm{M} \mathrm{NaCl}$ at $\mathrm{pH}$ 8.0. The extract was centrifuged at $5000 \mathrm{rpm}$ for 10 minutes. Fifteen $\mu \mathrm{l}$ of each supernatant was electrophoresed in $12 \%$ polyacrylamide-bisacarylamide gel. Gels were stained with $0.3 \%$ Coomassie Brilliant blue for 18 hours. Destaining was done in a mixture of methanol, acetic acid and distilled water $(1.3 \mathrm{v} / \mathrm{v})$. This was done overnight in order to visualize the protein bands for subsequent scoring. The gels were scanned with HP 3320 scanner and the images stored for scoring.

Single Linkage Cluster Anaysis (SCLA) was carried out on the data using Palaeontological Statistics, ver. 1.75 (PAST). Sokal and Sneath (1963) coefficient of similarity was used to show the level of similarity of protein profile of the taxa.

\section{Results and discussion}

The gel of the leaf protein electrophoresis of the six species of Jatropha studied is presented in Fig. 1 while the schematic diagram is shown in Fig. 2. The pattern of protein banding in the six Jatropha species revealed a total of 30 bands (Tab. 1), and protein banding in each species of Jatropha studied was species specific as no two species had completely the same profile. Distinct differences were observed not only in the number of bands and combination of bands but also in the intensity of bands. The result further shows that 16 bands (51.8\%) were fast bands, 10 (27.6\%) were intermediate in movement while 4 bands $(13.8 \%)$ were slow moving protein bands. Generic band occur at 8.3 though with varying degree of intensity in the species (with J. integerrima having the most intense of the generic band; Fig. 1).

Apart from the generic band, interspecific bands are widespread in the genus as observed in the bands at 3.3 (2 species), 3.8 (2 species) 6.3 (present in 3 species) and 8.9 (present in 4 species). Unique bands occur at 1.8, 2.4, 2.7, 2.9, 3.4, 4.5, 5.6, 5.8, 7.8 and 7.9 (Fig. 2). The highest number of interspecific bands (4) was found between $J$. podagrica and J. multifida while the pairs of J. podagrica and J. integerrima, J. podagrica and $J$ curcas as well as $J$. multifida and J. integerrima had three interspecific bands respectively. Sokal and Sneath coefficient of similarity revealed a generally low level of similarity in the leaf protein

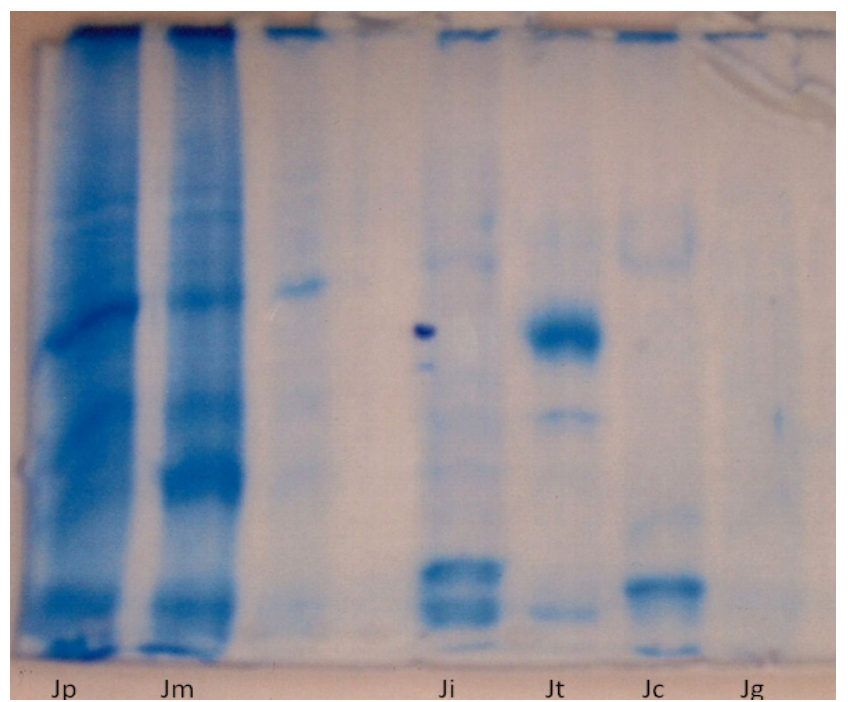

Fig. 1. Pattern of crude protein distribution in the leaf of Jatropha species

Tab 1. Protein band distribution in the six species of Jatropha in Nigeria

\begin{tabular}{cccccc}
\hline Species & $\begin{array}{c}\text { Slow } \\
\text { bands } \\
(0-3.0) \\
\mathrm{cm}\end{array}$ & $\begin{array}{c}\text { Intermediate } \\
\text { bands } \\
(3.1-6.0) \\
\mathrm{cm}\end{array}$ & $\begin{array}{c}\text { Fast } \\
\text { bands } \\
(6.1-9.0) \\
\mathrm{cm}\end{array}$ & $\begin{array}{c}\text { Total } \\
\text { number } \\
\text { of bands/ } \\
\text { species }\end{array}$ & $\begin{array}{c}\text { Unique } \\
\text { bands }\end{array}$ \\
\hline J.podagrica & 1 & 3 & 3 & 7 & 2 \\
J. multifida & 2 & 2 & 3 & 7 & 3 \\
J. integerrima & 1 & 2 & 4 & 7 & 4 \\
J. tanjorensis & - & 2 & 1 & 3 & 2 \\
J. curcas & - & 1 & 3 & 4 & 1 \\
\hline J. gossypifolia & - & & 1 & 1 & 0 \\
Total & 4 & 10 & 16 & 30 & \\
\hline
\end{tabular}


94

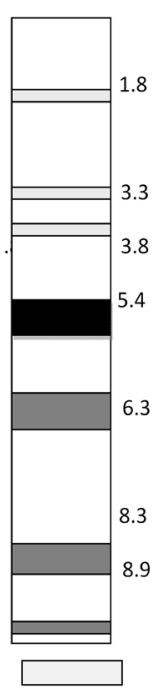

Very faint band

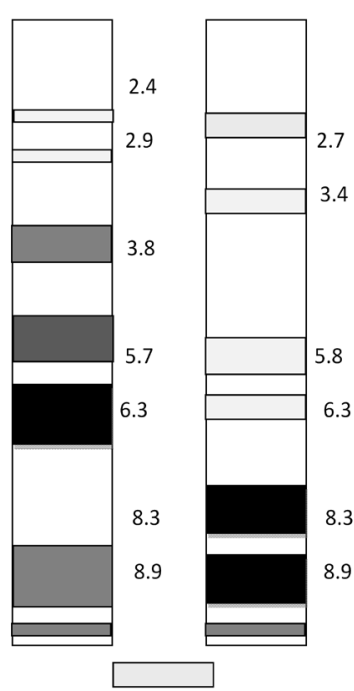

faint band

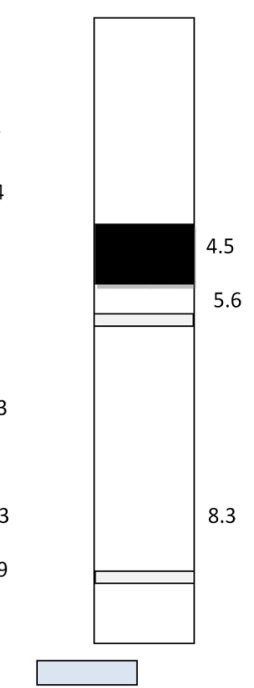

Fairly thick band

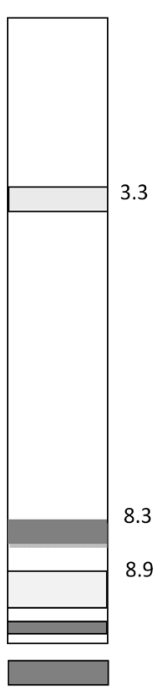

Thick band

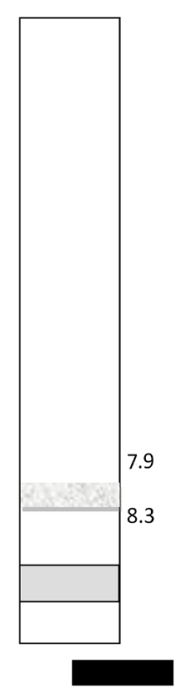

Very Thick band

Fig. 2. Schematic diagrams of leaf protein distribution pattern of six species of Jatropha in Nigeria

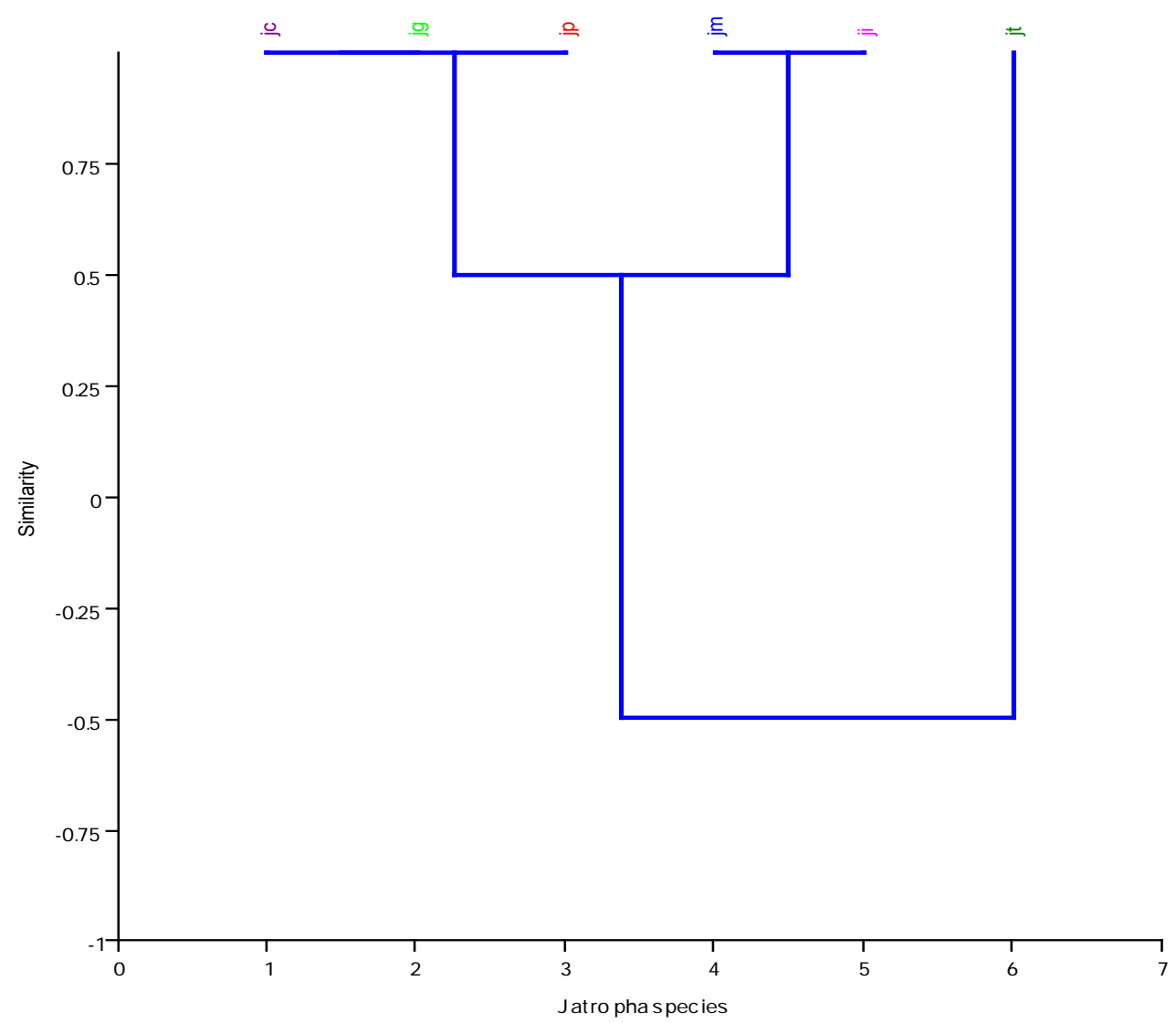

Fig. 3. Single Linkage Cluster Analysis (SLCA) dendogram of Relative mobility (Rm) values for leaf protein in the six species of Jatropha studied

bands of the six species studied and ranged from 11.1 to $44.4 \%$ (Tab. 2). The highest coefficient of similarity occured between J. podagrica and J. multifida (44.4\%). The Single Linkage Cluster Analysis (SCLA) dendogram of the relative mobility $(\mathrm{Rm})$ values of protein bands was presented in Fig. 3. The SLCA diagram shows the six species separated into 2 main groups with Jatropha tanjorensis being the only taxon on the first main cluster while the remaining five taxa form the second main cluster. J. multifida and J. integerrima appear the most closely related as they clustered to the highest level.

The variations observed in the distribution of protein bands in the genus are species-specific. This corroborates the report of Olson (1967) that biogenetic relationship 
Tab. 2. Sokal and Sneath similarity index for Jatropha species based on the Relative mobility (Rm) values

\begin{tabular}{|c|c|c|c|c|c|c|}
\hline & J.podagrica & J. multifida & J. integerrima & J. tanjorensis & J. curcas & J. gossypifolia \\
\hline J.podagrica & - & & & & & \\
\hline J. multifida & 44.4 & - & & & & \\
\hline J. integerrima & 27.3 & 27.3 & - & & & \\
\hline J. tanjorensis & 11.1 & 11.1 & 11.1 & - & & \\
\hline J.curcas & 37.5 & 25.0 & 22.2 & 20.0 & - & \\
\hline J. gossypifolia & 14.3 & 14.3 & 14.3 & 33.3 & 25.0 & - \\
\hline
\end{tabular}

can be best revealed by quantitative results emanating from chemotaxonomic methods. Similarly, the degree of variations observed in the protein profile of the taxa is indicative of the genetic divergence among the taxa studied. Gotlieb (1971) observed that the presence of common bands (e.g 8.3 in Fig. 2) in a group of taxa reflects evolutionary relationship. In this study, J. multifida and J. integerrima showed high level of relatedness (Fig. 3), however this contradicts the findings of Sudheer-Pamidiamarri et al. (2009). They reported high level phylogenetic closeness between J. curcas and J. integerrima in their study of genetic divergence and phylogenetic analyses of members of the genus Jatropha using nuclear ribosomal DNA ITS Sequence. The clear demarcation of J. tanjorensis from the rest of the taxa (Fig. 3), disagrees with reports from many researchers that the species is natural hybrid of J. curcas and J. gossypifolia. This finding also agrees with the result of Sudheer-Pamidiamarri et al. (2009). Sudheer-Pamidiamarri et. al (2009) in a comparative study of divergence within the genus using RAPD and AFLP techniques found nothing to support the view of J. tanjorensis as being a natural hybrid of J. curcas and J. gossypifolia Moreover, in a study of wood anatomy of some members of the genus Jatropha in Nigeria, Oladipo (2012) reported the presence of biseriate rays in J. tanjorensis which was not found in the other species, thus corroborating the uniqueness of the species. Similarly, Kanak et al. (2009) reported unique floral abnormalities peculiar to J. tanjorensis which make it the only species with such abnormalities leading to its complete sterility. Thus, further studies maybe necessary to ascertain the taxonomic position of the species (J.tanjorensis) as it affects its relationship to members of the genus Jatropha. The closeness observed between J. podagrica and J. multifida (Fig. 3 ) is in line with their current subgeneric and sectional delimitations based on their vegetative morphology, epidermal and petiole anatomy (Dehgan and Webster, 1979; Dehgan, 1980, 1982). Both species belong to the subgenus Jatropha and section Peltatae. Generally, the pattern of clustering observed in the SLCA (Fig. 3) largely contradicts the current sub generic delimitation of the taxa. Under the current classification, only J. curcas belongs to the subgenus Curcas while the remaining taxa belong to the subgenus Jatropha. It is interesting to note the close association of J. curcas (in the second sub cluster of the dendogram) with some members of the subgenus Jatropha. This is in line with the perception of the taxon as the most primitive and the possible ancestor from which other taxa evolved with structural modification (Dehgan and Webster, 1979). This pattern was also observed in a similar study carried out by Oladipo et al. (2008) using seed protein electrophoresis on four species of Jatropha. The differences observed in the protein profiles of the taxa studied are indicative of genetic diversity and thus, may be useful in the taxonomic delimitation of the members of the genus. Thus, leaf protein electrophoresis appear to demonstrate close relationship and distinctness of the members of genus studied and could therefore be important in their infra generic delimitations. J. tanjorensis should be subjected to further taxonomic study in view of its distinct protein profile compared to the remaining taxa in the genus.

\section{References}

Aguegia A, Fatokun CA, Hahn SK (1994). Leaf protein analysis of ten Cocoyam (Xanthosoma sagitifolium(L.) Schott and Colocasia esculenta (L) Schott genotypes. Proc of the Fifth Symposium ISTRC-AB, 348-353 p.

Akpabio KE (1988). Crude protein electrophoresis of seeds of eight species of Crotolaria L. Nigeria. J Botany 1:106-111.

David SS (1994). Phytochemistry and systematics of Euphorbiaceae. Ann Missouri Bot Gard 81(2):380-401.

Dehgan B, Webster GL (1979). Morphology and infrageneric relationship of the genus Jatropha (Euphorbiaceae). Univ California Publ Bot, vol. 74, 957-981 p.

Dehgan B (1980). Application of epidermal morphology to taxonomic delimitation in the genus Jatropha L. (Euphorbiaceae). Bot J Linn Soc London 80:257-278.

Dehgan B (1982). Comparative anatomy of the petiole and infrageneric relationship in Jatropha (Euphorbiaceae). Am J Bot 69(8): 1283-1295.

Domingues RM, Kaita MC, Avelar E, Sonza KES, Moraes WDGS, Franco EN (1988). Characterization of exposed outer membrane protein in environmental and human bacteroides fragile strains. Zbl Bakt 287(4):331-341.

Folorunso AE, Olorode O (2002). Electrophoresis of crude protein of seeds of some genera of Annonacaeae. Nig J Bot 7:916-919.

Gotlieb LD (1971). Gel electrophoresis. New approach to study of evolution. Bioscience 21(18):939-944. 
96

Hegnauer R (1989). Euphorbiaceae, 440-474 p. In: Chemotaxonomic der Pflanzer, Birkhauser Verlaj Basel, vol. 8.

Heller J. (1996). Physics nut- Jatropha curcas L. promoting conservation and use of underutilised and neglected crop 1. International Plant Genetic Resources Institute, Rome, Italy.

Kanak S, Susheel K, Krishna KR (2009). Floral abnormalities in Jatropha tanjorensis Ellis \& Saroja (Euphorbiaceae): a natural interspecific sterile hybrid. Plant Sci Biol 24:115-119.

Oladipo OT, Illoh HC, Odekanyin OO (2008). Crude protein electrophoresis of seeds of four Nigerian species of Jatropha Linn. (Euphorbiaceae). Ife J Sci 10(2):263-267.

Oladipo OT (2012). Biosystematic study of the genus Jatropha Linn. of the family Euphorbiaceae in Nigeria (Unpublished Ph.D Diss). Obafemi Awolowo University, Ile-Ife Nigeria.

Olowokudejo JD (1993). Comparative epidermal morphology of West African species of Jatropha L. (Euphorbiaceae). Bot J Linn Soc 111:139-154.

Olson U (1967). Chemotaxonomic analysis of some cytotypes in Mentha $x$ Verticillate complex (Labiatae). Botan Notiser 20: 255-267.

Omitogun OG, Jackal L, Thottappilly G (1999). Isolation of insecticidal lectin enriched extracts from African yam bean (Sphenostylis sternocarpon) and other legume species. Entomol Exp Appl 90:301-311.
Prabakaran AJ, Sujatha M (1999). Jatropha tanjorensis Ellis and Saroja: A natural specific hybrid occurring in Tamil Nadu, India. Gen Resour Crop Evol 46:213-218.

Rao LN (1971). Morphology and morphogenesis of foliar sclereids in Aegceras corniculatum. Israel J Bot 20:124-132.

Sokal RR, Sneath PHA (1963). Numerical taxonomy. Freeman WH (Ed.). San Fransisco.

Sudheer-Pamidiamarri DVN, Balaji C, Mupalla PR (2009). Genetic divergence and phylogenetic analysis of genus Jatropha based on ribosomal DNA ITS Sequence. Molec Biol Rep 36 (7):1929-1935.

Sudheer-Pamidiamarri DVN, Nirali P, Mupalla PR (2009). Comparative study of interspecific- genetic divergence and phylogenetic analysis of genus Jatropha by RAPD and AFLP. Molec Biol Rep 36(5):901-907.

Tokpo EY, Danquah EY, Ottfei SK, Bla ET (2006). Esterase, total protein and seed storage protein diversity in Okra (Abelmoschus esculentus (L) Moend. West Afr J Appl Ecol 9:177-183.

Webster GL (1994). Classification of the Euphorbiaceae. Ann Missouri Bot Gard 81(1):3-32. 